\title{
НОВИ УЏБЕНИК ДОБРЕ КОНЦЕПЦИЈЕ И САДРЖАЈА
}

Слободан Новокмет, Весна Ђорђевић, Јасмина Станковић, Светлана Стевановић, Јоле Булатовић. С речи на дела Граматика српског језика за седми разред основне школе. Београд: БИГЗ, 2019.

Др Слободан Новокмет, др Весна Ђорђевић, Јасмина Станковић, Светлана Стевановић и Јоле Булатовић написали су и објавили Граматику српског језика за седми разред основне школе школске 2018/19. године. Издавач је Београдски издавачко-графички завод (БИГЗ), уз одобрење Министарства просвете, науке и технолошког развоја Републике Србије. Наиме, БИГЗ је окупио своје ауторе граматика петог ${ }^{1}$ и шестог ${ }^{2}$ разреда основне школе и указао им поверење да заједнички напишу нови уџбеник граматику за седми разред основне школе. БИГЗ се одлучио за пет аутора ${ }^{3}$, јер њихове референце говоре много о њиховој високој стручности и педагошкој пракси.

Граматика је намењена ученицима седмог разреда основних школа и има за циљ да развије и негује љубав према српском језику, олакша учење матерњег језика и да стечено знање одмах примени на датим вежбањима у уџбенику. Намера аутора, пре свега, била је да ученицима понуде јединствену граматику која ће им бити прилагођена, разумљива и јасна, и како сами аутори кажу у Уводу, ученик треба да открива свет граматичких правила.

\footnotetext{
${ }^{1}$ Аутори Граматике за пети разред: Слободан Новокмет и Весна Ђорђевић

2 Аутори Граматике за шести разред: Јасмина Станковић, Светлана Стевановић и Јоле Булатовић.

${ }^{3}$ Слободан Новокмет, научни сарадник на Институту за српски језик САНУ; Весна Ђорђевић - сарадница на Институту за српски језик САНУ, Јасмина Станковић - ОШ „Ћирило и Методије”, Београд, члан НПС, педагошки саветник; Светлана Стевановић - ОШ „Херој Иван Мукер”, Смедеревска Паланка; Јоле Булатовић - ОШ „Дринка Павловић”, Београд.
} 
Граматика за 7. разред основне школе обухвата четири кључна поглавља: Граматика, Правопис, Правилан изговор, Језичка култура. Наведена поглавља обухватају тринаест области:

1. Научили смо у 6. разреду (обухвата градиво 6. разреда; приступ је обнављање кроз врло креативне и исходовне задатке).

2. Глаголски облици (императив, потенцијал, футур II, трпни глаголски придев, глаголски прилог садашњи, глаголски прилог прошли, подела глаголских облика).

3. Непроменљиве речи (везници, речце, узвици).

4. Синтагме (синтагма, именичке синтагме, атрибут у оквиру синтагме, придевске синтагме, прилошке синтагме, глаголске синтагме).

5. Реченични чланови (логички субјекат, сложени глаголски предикат, напоредни односи, конгруенција).

6. Комуникативне и предикатске реченице (комуникативне и предикатске реченице, независне и зависне предикатске реченице, реченични чланови исказани речју, предлошко-падежном конструкцијом, синтагмом и реченицом).

7. Независне предикатске реченице - напоредни односи (напоредни односи међу независним предикатским реченицама, саставни однос, супротни однос, раставни однос).

8. Зависне предикатске реченице (изричне, односне, месне, временске, узрочне, условне, допусне, намерне, последичне, поредбене, исти везници у различитим зависним реченицама).

9. Правопис (интерпункцијски знаци, писање скраћеница).

10. Правилан изговор (дугоузлазни и дугосилазни акценат).

11. Језичка култура (функционални стилови у српском језику, текст заснован на аргументима, технички и сугестивни опис, репортажа, цитати и фусноте, табеле, легенде, графикони, мапе ума, фразеологизми, језичке вежбе).

12. Завршни тест (обухвата целокупно градиво седмог разреда).

13. Индекс појмова.

Градиво је примерено и у складу са Наставним планом и програмом, врло прегледно, јасно, валидно, тачно и усклађено са потребама наставника за рад. Сви наставни садржаји једнако су детаљно обрађени и прилагођени ученицима седмог разреда основне школе, а задаци су постављени поступно - по стандардима. На самом почетку, поред мотивационе речи аутора, налази се Водич кроз уибеник који врло сликовито приказује шта све ученици и 
наставници могу да очекују у новом уџбенику добре концепције и садржаја: Подсетник (ученици могу да се подсете садржаја из претходних разреда), Корак напред (дати су додатни садржаји везани за наставни садржај), Важно (у овом одељку истичу се важни делови наставног садржаја), Буди истражсивач (разна упутства која ученике упућују на дигиталне садржаје), Како се пише? (важна правописна правила), Провежбајмо (сваки наставни садржај завршава се задацима), Да ли знаш? (разне занимљивости), Кључне речи (најважнији појмови истакнути су на крају лекције).

Свако поглавље почиње кратким описом предстојећих лекција. У опису, на левој страни, истакнути су исходи који су прилагођени ученичком језику (нпр.: У овом поглављу научићеш: да разликујеш граматички и логички субјекат, шта је конгруенција, правила за употребу црте и заграде, како се скраћују речи, каква је интонација дугосилазног акцента, каква је интонација дугоузлазног акцента, шта су устаљени изрази (фразеологизми) и када се користе, зашто је важно чињенично (аргументовано) казивање...), а на десној страни је духовита илустрација везана за наставни садржај. Наставни садржаји објашњени су веома исцрпно и поступно, пропраћени великим бројем примера који су примерени савременом наставнику и ученику, те делују јако мотивационо. Формулације и методичко-дидактичке апаратуре прилагођене су ученицима седмог разреда основне школе, што говори о професионалности излагања аутора, као и о њиховој великој усредсређености на материју. О овоме сведочи и чињеница да су наставни садржаји повезани са садржајима из књижевности. Свака област завршава се врло прегледном систематизацијом и тестом којим се утврђује и систематизује знање питањима основног, средњег и напредног нивоа.

Посебно је упечатљива рубрика Буди истраживач у којој нас аутори упућују на различите дигиталне садржаје с циљем да се ученици на један други начин заинтересују за наставне садржаје и прошире своје знање. Ученицима се дају следећа упутства: Прочитај на сајту јezikofil.rs текст Да ли сам довезен или довежен?; или: Када хоћемо да забележимо лавеж пса, користимо узвике ав-ав. Истражи на интернету како се на другим језицима обележава лавеж пса; или: Прочитај на сајту vokabular.org шта још синтагма означава; или: Провери на сајту vokabular.org из ког језика долази реч конгруенщија; или; О употреби израза будући да сазнај више на сајту jezikofil.rs. Такође, у овој рубрици ученици добијају идеје за разне пројектне задатке и наводе ученике да језичка знања повезују са другим предметима.

Уџбеник је веома јасан и прегледан, богат разним табелама и дијаграмима које на крајње модеран и једноставан начин објашњавају 
наставне садржаје. Велики број илустрација има за циљ да што више заинтересује ученика. Илустрације су функционалне, атрактивне, модерне и шаљиве. Научни стил аутора је веома јасан, разумљив и прецизан, а има за циљ да ученици што боље схвате граматичка правила, као и да иста примене у писању и говору. Граматика 7 написана је студиозно и стручно и пружа исцрпну и разрађену грађу, поштујући све критеријуме Стандарда квалитета уџбеника. Еминентни рецензенти: проф. др Вељко Брборић, Миљана Степаноски, мср Ивана Костић и мср Ива Златић потврђују да Граматику одликују стручност аутора и методичка пракса.

Научност, стручност и методички осећај за ученички узраст потврђују да је Граматика $C$ речи на дела с правом један од обавезних уџбеника за ученике седмог разреда.

Марија В. Запутил

ШОСМО „Стеван Мокрањац”, Пожаревац Пожаревачка гимназија, Пожаревац marija.zaputil@gmail.com

Примљено: 24. 4. 2020. Прихваћено: 5. 6. 2020. 